\title{
Hubungan Perilaku Tindakan Pencegahan Terhadap Kejadian ISPA Saat Kabut Asap Di Kota Pontianak
}

\section{Relationship Of Precautions Behaviour Towards Acute Respiratory Tract Infections During Smoke Fog In The City Of Pontianak}

\author{
Epiphana Desi ${ }^{1}$, Sukarni $^{2}$, Djoko Priyono $^{3}$ \\ ${ }^{1}$ Mahasiswi Prodi Keperawatan Fakultas Kedokteran Universitas Tanjungpura, Pontianak \\ epiphanadesi26@student.untan.ac.id \\ ${ }^{2}$ Dosen Keperawatan Fakultas Kedokteran Universitas Tanjungpura, Pontianak Sukarni@ners.untan.ac.id \\ ${ }^{3}$ Dosen Keperawatan Fakultas Kedokteran Universitas Tanjungpura, Pontianak djokopri07@gmail.com
}

\begin{abstract}
ABSTRAK
Latar Belakang: Infeksi Saluran Pernapasan Akut (ISPA) merupakan infeksi akut yang menyerang salah satu bagian atau lebih dari saluran pernapasan mulai dari hidung sampai alveoli termasuk adneksanya (sinus, rongga telinga tengah, pleura). Terjadinya penurunan kualitas udara Kota Pontianak akibat dari peristiwa kebakaran hutan dan lahan menyebabkan peningkatan jumlah penderita penyakit Infeksi Saluran Pernafasan Akut (ISPA) dan gangguan saluran pernafasan lainnya. Faktor yang berperan dalam menentukan derajat kesehatan adalah perilaku. Perilaku tersebut dapat diatasi dengan melakukan tindakan pencegahan terhadap penyakit ISPA. Pencegahan merupakan mengambil sebuah tindakan sebelum terjadinya suatu penyakit. Tujuan: Mengetahui hubungan antara perilaku tindakan pencegahan terhadap kejadian ISPA saat kabut asap di Kota Pontianak. Metode: Jenis penelitian kuantitatif dengan desain penelitian descriptive correlational melalui rancangan penelitian survei kasus kontrol (Case Control). Teknik sampling yang digunakan adalah accidental sampling dengan jumlah 40 responden. Instrumen yang digunakan adalah kuesioner perilaku tindakan pencegahan dan menggunakan uji Chi Square. Hasil: Sebagian besar responden berusia dewasa akhir dengan persentase $35.0 \%$. perempuan merupakan jenis kelamin tertinggi $65.0 \%$, pendidikan terbanyak adalah SMA 50.0\%, pekerjaan terbanyak adalah ibu rumah tangga (IRT) $45.0 \%$, perilaku tindakan pencegahan baik 55.0\%, dan kejadian ISPA adalah responden yang mengalami ISPA sebanyak $50.0 \%$. Hasil yang didapatkan menggunakan uji $C h i$ Square menunjukkan bahwa $P$ value 0,525 $(<0.05)$. Kesimpulan: Tidak terdapat hubungan antara perilaku tindakan pencegahan terhadap kejadian ISPA saat kabut asap di Kota Pontianak.

Kata Kunci: Perilaku Tindakan Pencegahan, Kejadian Infeksi Saluran Pernapasan Akut (ISPA).
\end{abstract}

Referensi: 69 (1980 - 2019) 


\title{
Relationship Of Precautions Behaviour Towards Acute Respiratory Tract Infections During Smoke Fog In The City Of Pontianak
}

\begin{abstract}
Background: Acute respiratory tract infection (ARI) is an acute infection that attacks one or more parts of the respiratory tract infections, ranging from the nose to the alveoli, including its adnexas such as sinus, middle ear cavity and pleural. The occurrence of air quality decline in Pontianak City as the results of forest and land fires causes increasing number of patients with acute respiratory tract infections and other respiratory tract disorders. Factor that play a role in the determining the degree of health are behaviors. Such behaviour can be addressed by the prevention of acute respiratory tract infections. Prevention is taking an action before the disease occurs. Objectives : Discover the relationship between precautionary behaviour towards acute respiratory tract infections during smoke fog in Pontianak City. Method: Quantitative study design with descriptive correlational through case control survey research plan. The sampling technique used was accidental sampling with total 40 respondents. The instrument used is a quessionaire for precautionary behaviours and Chi square test. Result: Most respondents are late adults (35\%), Women placed the highest sex rate by 65\%, half of them have their high school degree (50\%) and most of respondents are housewives (45\%), good measurement for precautionary behaviours detected (55\%) and half of them experienced acute respiratory tract diseases. The result obtained by using chi square shows that $P$ value is 0,525 $(<0,005)$. Conclusion: There is no link between precautionary behaviours towards acute respiratory tract infections in Pontianak City.
\end{abstract}

Keywords : Precautionary Behaviours, The Incident Of Acute Respiratory Tract Infection (ARI)

References: $69(1980-2019)$ 


\section{PENDAHULUAN}

Infeksi Saluran Pernapasan Akut (ISPA) merupakan infeksi akut yang menyerang salah satu bagian atau lebih dari saluran pernapasan mulai dari hidung sampai alveoli termasuk adneksanya (sinus, rongga telinga tengah, pleura) ${ }^{1}$. Penyakit ini diawali dengan rasa panas, kering dan gatal, kemudian diikuti bersin secara terus menerus, hidung mengalami sumbatan dengan sekret encer, demam dan nyeri kepala, permukaan mukosa hidung tampak merah sehingga mengalami peradangan bila tidak ada komplikasi gejalanya akan berkurang sesudah 3-5 hari ${ }^{2}$.

Berdasarkan Riset Kesehatan Dasar pada tahun 2013-2018 prevalensi penyakit ISPA di Indonesia sebesar 4,4\%. Prevalensi penderita ISPA yang paling tinggi yaitu di Provinsi Papua yang mencapai 10,5\%. Kalimantan Barat menjadi urutan ke 20 penderita ISPA dengan prevalensi sebesar $3,2 \%^{3}$. Hasil studi pendahuluan di Dinas Kesehatan Provinsi Kalimantan Barat jumlah kasus ISPA pada seluruh masyarakat berfluktuatif, kasus ISPA diakibatkan kabut asap perbulan (Agustus-Oktober) pada tahun 2017 sebesar 49,877 dan pada tahun 2018 kasus ISPA yang diakibatkan kabut asap perbulan (Januari-Agustus), pada bulan Agustus mengalami penurunan yaitu sebesar 12,795 dibanding bulan januari yaitu sebesar $26,917^{4}$.

Hasil studi pendahuluan peneliti di dinas Kesehatan Kota Pontianak, kasus Infeksi Saluran Pernapasan Akut (ISPA) di kota Pontianak, Kalimantan Barat, mengalami penurunan dibandingkan tahun sebelumnya, meskipun mengalami penurunan setiap tahunnya kabut asap semakin pekat melanda kota Pontianak. Tahun 2017 mengalami penurunan dalam satu tahun yaitu sebesar 35,953 dan pada tahun 2018 mengalami penurunan sebesar
23,052. Puskesmas Saigon merupakan salah satu dari 24 Puskesmas yang ada di Kota Pontianak dengan angka kejadian ISPA yang tertinggi pada tahun 2018 . Hasil studi pendahuluan peneliti angka kejadian ISPA pada bulan 1 Agustus- 31 oktober tahun 2018 sebesar 1,4095.

Pulau Kalimantan adalah salah satu pulau yang sering terjadi kebakaran hutan dan lahan dimana seluruh Provinsi pernah terbakar salah satunya yaitu Provinsi Kalimantan Barat ${ }^{6}$. Kasus ISPA termasuk pneumonia setiap tahunnya selalu menempati urutan pertama dalam sepuluh kasus penyakit terbesar di Kota Pontianak. Terjadinya kabut asap di Kota Pontianak diakibat adanya transboundary haze pollution. Titik panas (hotspot) merupakan pemicu terjadinya kabut asap di Kota Pontianak dan sebagian besar bukan berasal dari wilayah itu sendiri. Penyebab kebakaran terjadi karena aktivitas pembukaan hutan dan ladang tidak terjadi di wilayah tersebut, tetapi di kabupaten terdekat dari Kota Pontianak, apabila ada titik hotspot di wilayah tersebut biasanya dalam jumlah yang sangat kecil ${ }^{7}$. Masalah yang di timbulkan oleh asap seperti iritasi mata, kulit dan gangguan saluran pernapasan yang berat, berkurangnya fungsi paru, bronkitis, dan asma. Konsentrasi yang tinggi dari partikelpartikel iritasi pernapasan dapat menyebabkan batuk dan sesak napas. Materi partikulat juga dapat memengaruhi sistem kekebalan tubuh karena terhirupnya benda asing ke paru ${ }^{8}$. Selain itu kabut asap dapat menimbulkan gangguan jarak pandang atau pengelihatan, sehingga dapat menganggu semua aktivitas di luar rumah ${ }^{9 ; 10}$.

Mengingat bahayanya pengaruh dari kabut asap bagi kesehatan manusia yang tidak hanya menyerang sistem pernapasan tetapi dapat menyerang sistem kardiovaskuler bahkan menyebabkan 
kematian, peran perawat sangat penting dalam hal ini. Perawat mempunyai peran dalam melakukan asuhan keperawatan untuk masyarakat yang terkena dampak dari kabut asap. Perawat merupakan garis terdepan dalam perawatan masyarakat. Peran perawat yaitu menciptakan lingkungan yang sehat ${ }^{8}$.

Penelitian ini menggunakan pendekatan perilaku masyarakat. Perilaku tersebut dapat diatasi dengan melakukan tindakan pencegahan terhadap penyakit ISPA. Pencegahan merupakan mengambil sebuah tindakan sebelum terjadinya suatu penyakit. Ada 3 dasar yang menjadi tingkatan pencegahan penyakit yaitu, pencegahan tingkat pertama yaitu usaha sungguh-sungguh untuk menghindari suatu penyakit atau tindakan kondisi kesehatan yang merugikan dengan melalui kegiatan promosi kesehatan dan tindakan perlindungan. Tindakan kedua yaitu, dektesi dini dengan pengobatan yang tepat, dan tindakan ketiga yaitu mencegah jangan sampai penderita mengalami cacat atau permanen ${ }^{11 ; 12}$. Oleh karena itu peneliti tertarik untuk mengambil penelitian yang berjudul "Hubungan Perilaku Tindakan Pencegahan Terhadap Kejadian ISPA Saat Kabut Asap Di Kota Pontianak".

\section{METODE}

Penelitian ini merupakan penelitian kuantitatif dengan desain penelitian descriptive correlational dengan rancangan penelitian survei kasus kontrol (Case Control), yaitu desain penelitian yang bertujuan untuk mengetahui hubungan antara variabel independen dan variabel dependen berdasarkan perjalanan waktu. Jumlah responden dalam penelitian ini adalah sebanyak 20 terkena ISPA dan 20 tidak ISPA menggunakan teknik sampel non probability sampling dengan accidental sampling ${ }^{13}$. Instrumen yang digunakan adalah karakteristik responden dan perilaku tindakan pencegahan yang telah diuji valid di Puskesmas Parit Mayor Pontianak Timur. Untuk kategori perilaku tindakan pencegahan dengan nilai baik, jika skor $\geq 30$ dan kurang, jika skor $\leq 30$. Analisis data menggunakan analisis statistik di komputer. Setelah data terkumpul kemudian dilakukan pemgolahan data menggunakan Uji ChiSquare

\section{HASIL DAN PEMBAHASAN}

Tabel 1 Distribusi Frekuensi Karakteristik Demografi $(\mathrm{n}=40)$

\begin{tabular}{|c|c|c|}
\hline $\begin{array}{c}\text { Karakteristik } \\
\text { Responden }\end{array}$ & (f) & $(\%)$ \\
\hline \multicolumn{3}{|l|}{ Usia } \\
\hline $17-25$ & 6 & 15.0 \\
\hline $26-35$ & 13 & 32.5 \\
\hline $36-45$ & 14 & 35.0 \\
\hline $46-55$ & 5 & 12.5 \\
\hline $56-65$ & 1 & 2.5 \\
\hline$<65$ & 1 & 2.5 \\
\hline Total & 40 & 100 \\
\hline \multicolumn{3}{|l|}{ Jenis Kelamin } \\
\hline Laki-laki & 14 & 35.0 \\
\hline Perempuan & 26 & 65.0 \\
\hline Total & 40 & 100.0 \\
\hline \multicolumn{3}{|l|}{ Pendidikan } \\
\hline $\mathrm{SD} /$ Sederajat & 3 & 7.5 \\
\hline SMP/Sederajat & 6 & 15.0 \\
\hline SMA/Sederajat & 20 & 50.0 \\
\hline Perguruan Tinggi & 11 & 27.5 \\
\hline Total & 40 & 100.0 \\
\hline \multicolumn{3}{|l|}{ Pekerjaan } \\
\hline Buruh & 2 & 5.0 \\
\hline $\begin{array}{l}\text { Pedagang/Wirasw } \\
\text { asta }\end{array}$ & 5 & 12.5 \\
\hline PNS & 4 & 10.0 \\
\hline $\begin{array}{ll}\text { Ibu } & \text { Rumah } \\
\text { Tangga } & \end{array}$ & 18 & 45.0 \\
\hline
\end{tabular}




\begin{tabular}{lcc} 
Lainnya & 11 & 27.5 \\
Total & 40 & 100.0 \\
\hline
\end{tabular}

Sumber: Data Primer, 2019

Berdasarkan kategori usia dapat terlihat bahwa jumlah terbanyak berasal dari responden yang berusia dewasa akhir yaitu sebanyak 14 responden (35.0\%). Menurut hasil penelitian Awaluddin, (2016 usia produktif orang banyak melakukan aktivitas diluar rumah sehingga peluang terpapar asap menjadi lebih lama. Hal tersebut yang menyebabkan tingginya angka kejadian keluh kesehatan akibat kabut asap akan mengalami penurunan fungsi tubuh. Orang berusia tua mudah terpengaruh oleh asap karena mekanisme pertahanan saluran pernapasan mereka terutama fungsi pembersih partikel berkurang ${ }^{14 ; 8}$. Menurut peneliti usia seseorang mempengaruhi kemampuan seseorang untuk menerima informasi dan pola pikir seseorang tentang informasi yang diberikan. Semakin bertambahnya usia maka kemampuan informasi dan pola pikir seseorang semakin berkembang dan seseorang mampu untuk menerima informasi yang diberikan. Sebagian besar responden sudah menganggap betapa pentingnya mendeteksi bagaimana perilaku tindakan pencegahan terhadap kejadian ISPA sedini mungkin.

Kategori jenis kelamin yang terbanyak yaitu perempuan sebanyak 26 responden $(65.0 \%)$ sedangkan berjenis kelamin laki-laki sebanyak 14 responden (35.0\%). Pada umumnya tidak terdapat perbedaan insiden ISPA akibat virus atau bakteri baik pada laki-laki dan perempuan. Akan tetapi ada yang berpendapat bahwa terdapat sedikit perbedaan dimana insiden lebih tinggi pada anak laki-laki ${ }^{15}$. Hal ini di dukung oleh penelitian yang dilakukan Novita (2008) hasil penelitian yang dilakukan bahwa laki-laki lebih banyak terserang penyakit ISPA dibandingkan perempuan hal tersebut dikaitkan dengan adanya perbedaan perilaku dan lingkungan dan aktivitas laki-laki yang lebih tinggi di luar rumah daripada perempuan sehingga resiko kontak dengan agen penyakit lebih tinggi ${ }^{16}$. Widaningsih, (2018) mengatakan bahwa tindakan pencegahan yang baik yaitu perempuan karena biasanya perempuan lebih memperhatikan kondisi kesehatan diri dan keluarganya dibanding dengan laki-laki sehingga perempuan cenderung langsung mengunjungi puskesmas saat memiliki keluhan kesehatan ${ }^{17}$.

Berdasarkan penjelasan diatas, didapatan hasil penelitian sesuai dengan teori dan hasil penelitian yang ada. Dimana didapatkkan perempuan lebih cenderung memilki perilaku tindakan pencegahan yang baik di bandingkan lakilaki terhadap kejadian ISPA. Hal lain yang mungkin berpengaruh adalah ketika peneliti melakukan penelitian di Puskesmas Saigon didapatkan rata-rata responden yang berkunjung di Puskesmas didominasi oleh perempuan.

Pada kategori pendidikan terdapat responden yang memiliki tingkat pendidikan yang terbanyak yaitu tingkat SMA/Sederajat sebanyak 20 responden (50.0\%). Menurut penelitian yang dilakukan Lebuan (2017) berdasarkan teori, seseorang dengan tingkat pendidikan rendah dikatakan faktor terjadinya ISPA dikarenakan mereka cenderung tidak awas terhadap tanda dan gejala awal munculnya penyakit ISPA yang menyebabkan keterlambatan dalam penanganan, bahkan bisa menimbulkan komplikasi yang berat seperti pneumonia, dan lain-lain ${ }^{18}$. Tingkat pedidikan seseorang akan menentukan pola pikir dan wawasan semakin tinggi pendidikan manusia dianggap akan memperoleh pengetahuan dan semakin 
tinggi pendidikan maka akan semakin berkualitas ${ }^{19}$.

Pada kategori pekerjaan responden terbanyak berprofesi sebagai ibu rumah tangga yaitu sebanyak 18 responden (45.0\%). Hasil penelitian juga didukung oleh Putra (2017) keinginan ibu untuk menjadi ibu rumah tangga karena ingin merawat anaknya sendiri dengan baik sehingga dapat memantau perkembangan dan pertumbuhan anak balitanya ${ }^{20}$. Hasil penelitian juga didukung oleh Milo (2015) dengan kejadian ISPA di dapatkan bahwa sebagian responden dengan pekerjaan ibu rumah tangga yaitu sebanyak 40 responden (78.4\%). Seseorang yang bekerja pengetahuannya akan lebih luas dibandingkan dengan seseorang yang tidak bekerja karena dengan bekerja seseorang akan mempunyai banyak informasi dan pengalaman ${ }^{21}$.

Berdasarkan dengan hasil penelitian sebelumnya dalam penelitian ini menyatakan bahwa mayoritas responden berprofesi sebagai ibu rumah tangga, dimana menunjukkan status kerja ibu (bekerja atau tidak bekerja) dapat mempengaruhi kesehatan terutama kesehatan keluarga, karena ibu yang bekerja memiliki waktu yang lebih sedikit untuk merawat keluarga. Keluarga dari ibu yang tidak bekerja memiliki keuntungan dibandingkan keluarga dari ibu yang bekerja, menyangkut penyediaan makanan dengan gizi yang lebih dan menciptakan lingkungan rumah yang sehat.

Tabel 2 Distribusi Frekuensi Perilaku Tindakan Pencegahan

\begin{tabular}{lll}
\hline $\begin{array}{c}\text { Perilaku } \\
\text { Tindakan } \\
\text { Pencegahan }\end{array}$ & (f) & $(\%)$ \\
\hline Baik & 22 & 55.0 \\
Kurang & 18 & 45.0 \\
\hline
\end{tabular}

\begin{tabular}{lll}
\hline Total & $40 \quad 100.0$
\end{tabular}

Sumber: Data Primer, 2019

Hasil penelitian menunjukkan bahwa setengah dari responden memiliki tindakan pencegahan yang baik yaitu sebanyak 22 responden dari 40 responden $(55.0 \%)$, dan mempunyai tindakan pencegahan yang kurang yaitu sebanyak 18 responden dari 40 responden $(45.0 \%)$. Menurut Quasim (2018) pengetahuan yang dimiliki dapat mendorong seseorang untuk menciptakan kontrol perilaku yang baik pula, sehingga dengan mengetahui tentang ISPA dapat memberikan motivasi kepada seseorang untuk senantiasa melakukan upaya pencegahan ISPA. Pengetahuan yang baik disisi lainnya dapat meningkatkan sikap sehingga upaya pencegahan terlihat lebih baik dikarenakan pengetahuan dan sikap mereka sejalan dengan tujuan bagaimana tetap peduli dengan kesehatan baik upaya pencegahan ISPA $^{22}$.

Tabel 3 Distribusi Frekuensi Kejadian ISPA

\begin{tabular}{lcc}
\hline $\begin{array}{c}\text { Riwayat } \\
\text { Penyakit }\end{array}$ & (f) & $(\boldsymbol{\%})$ \\
\hline ISPA & 20 & 50.0 \\
Tidak ISPA & 20 & 50.0 \\
\hline Total & 40 & 100.0 \\
\hline
\end{tabular}

Sumber: Data Primer, 2019

Hasil penelitian menunjukkan bahwa sebagian besar responden memiliki riwayat penyakit masa lalu yaitu sebanyak 20 responden dari 40 responden $(50.0 \%)$ penyakit ISPA dan 20 responden dari 40 rsponden $(50.0 \%)$ tidak ISPA. Perjalanan penyakit akibat kabut asap dapat bersifat akut dan kronis. Paparan kabut asap dapat menyebabkan masalah kesehatan akut seperti ISPA. Kurangnya sinar matahari akibat terhalang kabut asap dapat 
menyebabkan peningkatan penyebaran virus maupun bakteri yang seharusnya dapat dibunuh oleh sinar ultraviolet. Mekanisme munculnya gangguan kesehatan akibat pengaruh asap terjadi melalui berbagai tahap yaitu iritasi langsung pada saluran pernapasan, sesak akibat kurangnya oksigen, serta absorpsi toksin. Hal yang dapat dicegah untuk mengurangi dampak kabut asap yaitu tetap berada di dalam rumah dan tutup jendela, segera lakukan evakuasi selektif bagi yang beresiko seperti bayi, ibu hamil, orang tua atau lansia, dan penderita gangguan pernapasan ke tempat yang bebas dari pencemaran udara ${ }^{24}$

\section{ANALISA BIVARIAT}

Tabel 4 Hasil uji uji Chi-Square untuk analisis hubungan perilaku tindakan pencegahan terhadap kejadian ISPA

\begin{tabular}{|c|c|c|c|c|c|c|c|}
\hline \multirow{4}{*}{$\begin{array}{c}\text { Perilaku } \\
\text { Tindaka } \\
\text { n } \\
\text { Pencega } \\
\text { han }\end{array}$} & \multicolumn{4}{|c|}{ Kejadian ISPA } & \multicolumn{2}{|c|}{ Jumla } & \multirow[b]{2}{*}{$\begin{array}{c}P \\
\text { Val }\end{array}$} \\
\hline & \multicolumn{2}{|c|}{ ISPA } & \multicolumn{2}{|c|}{$\begin{array}{c}\text { Bukan } \\
\text { ISPA }\end{array}$} & \multicolumn{2}{|c|}{ h } & \\
\hline & (f & $(\%$ & (f & $(\%$ & (f & $(\%$ & ue \\
\hline & ) & ) & ) & ) & ) & ) & \\
\hline \multirow[t]{2}{*}{ Baik } & 1 & 25 . & 1 & 30 . & 2 & 55 & \\
\hline & 0 & 0 & 2 & 0 & 2 & 0 & 0,52 \\
\hline \multirow[t]{2}{*}{ Kurang } & 1 & 25 . & 8 & 20. & 1 & 45 & 5 \\
\hline & 0 & 5 & & 0 & 8 & 0 & \\
\hline \multirow[t]{2}{*}{ Total } & 2 & 50 . & 2 & 50. & 4 & 10 & \\
\hline & 0 & 0 & 0 & 0 & 0 & 0 & \\
\hline
\end{tabular}

Sumber: Uji Chi Square, 2019.

Dari hasil diatas didapatkan nilai $p$ pada uji chi-square adalah 0,525 dimana nilai tersebut >0,05 maka dari nilai tersebut dapat disimpulkan bahwa tidak terdapat hubungan antara perilaku tindakan pencegahan terhadap kejadian ISPA di Kota Pontianak. Menurut penelitian Sofia, (2017) mengatakan tidak ada hubungan kejadian ISPA dengan disebabkan karena pembakaran sampah berada di luar rumah, asap hasil pembakaran tidak langsung terhirup melainkan dapat terbawa sesuai arah angin yang berhembus ${ }^{25}$. Hasil wawancara yang dilakukan peneliti didapatkan bahwa masyarakat yang berobat di Puskesmas Saigon rata-rata memiliki tindakan pencegahan yang baik. Responden yang tidak terkena ISPA dan yang pernah terkena ISPA mememiliki tindakan pencegahan yang baik dan sudah mengetahui bagaimana melakukan tindakan pencegahan ISPA ketika terjadinya kabut asap. Salah satu upaya penceghan yang biasa dilakukan masyarakat ketika menghadapi kabut asap yaitu menggunakan masker ketika diluar rumah, membatasi diri untuk mengurangi aktivitas diluar, banyak mengkonsumsi air putih untuk mencegah terjadinya dehidrasi dan sakit tenggorokan, kemudian tidak membakar sampah disekitar rumah dan membiasakan diri membuang sampah di penampungan yang sudah disedikan oleh petugas kebersihan.

Selain dari hasil pembakaran terdapat faktor lain yang mempengaruhi kejadian ISPA. Hal ini sejalan dengan penelitian yang dilakukan oleh Mayasari (2015) dimana dalam penelitian ini menunjukkan ada pengaruh status rumah yaitu bahan bangunan, lantai, dan ventilasi terhadap kejadian ISPA. Hal tersebut tidak terlepas dari perilaku dan pengetahuan masyarakat dalam membangun rumah yang masih jauh dari standar kesehatan. Oleh karena itu perlu adanya sosialisasi dari pihak terkait yaitu tenaga kesehatan sehingga masyarakat dapat memahami secara baik dan benar tentang membangunan rumah yang tidak sesuai standar kesehatan sangat beresiko menimbulkan penyakit ISPA pada penghuni rumah ${ }^{26}$.

Hasil penelitian yang dilakukan oleh Lebuan (2017) menyatakan bahwa 
terdapat hubungan antara paparan asap rokok dengan kejadian ISPA. Hal ini dijelaskan bagaimana asap rokok bisa meningkatkan resiko terinfeksi ISPA. Asap rokok baik dari orang tua atau penghuni rumah satu atap dapat mencemari udara, dan apabila terhirup oleh anak dapat merusak pertahanan saluran pernapasan, sehingga pathogen penyebab ISPA mudah masuk dan menginfeksi anak yang menimbulkan manifestasi klinis ISPA. Tidak hanya kabut asap saja yang menyebabkan terjadinya ISPA. Terdapat faktor lain yang mempengaruhi seperti usia, jenis kelamin, pendidikan dan pekerjaan ${ }^{18}$.

Usia yang rentan terkena ISPA terjadi pada bayi dan lansia, namun pada penelitian yang dilakukan peneliti didapatkan bahwa yang mudah terkena ISPA yaitu dewasa akhir dimana didapatkan bahwa dewasa akhir lebih banyak melakukan aktivitas diluar rumah sehingga rentan terkena paparan dari kabut asap ataupun polusi udara. Jenis kelamin yang banyak terkena ISPA biasanya terdapat pada laki-laki hal ini dikarenakan laki-laki lebih banyak melakukan aktivitas di luar rumah seperti bekerja dan jarang menggunakan masker di karenakan banyak yang mengatakan sesak napas ketika menggunakan masker dan rasa tidak nyaman. Berbanding terbalik dengan perempuan dimana perempuan memiliki perilaku tindakan pencegahan lebih baik dari pada laki-laki.

Dalam penelitian ini didapatkan sebagian responden memiliki tingkat pendidikan SMA. Sesuai hasil penelitian sebelumnya menyatakan bahwa tingkat pendidikan berpengaruh terhadap perilaku seseorang dalam melakukan suatu tindakan pencegahan terhadap penyakit. Dalam penelitian ini menyatakan bahwa mayoritas responden berprofesi sebagai ibu rumah tangga, dimana menunjukkan status kerja ibu (bekerja atau tidak bekerja) dapat mempengaruhi kesehatan terutama kesehatan keluarga, karena ibu yang bekerja memiliki waktu yang lebih sedikit untuk merawat keluarga. Keluarga dari ibu yang tidak bekerja memiliki keuntungan dibandingkan keluarga dari ibu yang bekerja, menyangkut penyediaan makanan dengan gizi yang lebih dan menciptakan lingkungan rumah yang sehat.

Begitu pentingnya pengetahuan dalam mempengaruhi seseorang dalam upaya mencegahan penyakit ISPA maka peran petugas kesehatan sangat signifikan dalam meningkatkan pengetahuan seseorang tentang pencegahan ISPA melalui sosialisasi dan penyuluhan secara intensif dan terperinci dan menggunakan bahasa yang mudah dimengerti oleh masyarakat mengenai pengertian ISPA, pencegahan ISPA, dampak ISPA serta diharapkan dengan meningkatnya pengetahuan dapat menumbuhkan kesadaran seseorang untuk menerapkan pengetahuan tersebut kedalam aplikasi pencegahan ISPA.

Beberapa upaya pencegahan tehadap munculnya penyebaran penyakit ISPA yaitu perilaku cuci tangan pakai sabun yang sesuai dengan tatanan rumah tangga merupakan langkah awal yang perlu mendapat perhatian oleh instansi pelayanan kesehatan terdepan yaitu Puskesmas, untuk keadaan pencahayaan rumah penderita yang belum memenuhi syarat dapat disikapi dengan pencahayaan buatan seperti lampu pijar dan juga menambahkan genteng kaca pada atap rumah sedangkan untuk ventilasi permanen rumah penderita ISPA yang belum memenuhi syarat dapat diantisipasi dengan ventilasi yang bersifat tidak tetap seperti pintu atau jendela ${ }^{23}$. 


\section{KESIMPULAN}

Berdasarkan hasil analisa data
distribusi frekuensi karakteristik
demografi didapatkan bahwa rata-rata
responden mempunyai usia berkisar antara
$36-45$ tahun dengan persentase $35.0 \%$,
berjenis kelamin perempuan dengan
persentase $65.0 \%$, untuk pendidikan
didapatkan bahwa sebagian besar
responden memiliki tingkat pendidikan
SMA/Sederajat dengan persentase50.0\%,
untuk pekerjaan hampir setengah
responden adalah ibu rumah tangga
$45.0 \%$ Sebagian besar responden
memiliki perilaku tindakan pencegahan
yang baik. Penelitian ini menunjukkan
tidak ada hubungan perilaku tindakan
pencegahan terhadap kejadian ISPA saat
kabut asap.

\section{SARAN}

Sebaiknya institusi kesehatan tetap memberikan penyuluhan berkaitan dengan perilaku pencegahan terhadap kejadian ISPA saat kabut asap, dan sebagai masukan yang berhubungan dengan bagaimana pola penerepan perilaku yang sehat yaitu dengan cara meningkatkan program promosi kesehatan terutama perilaku tindakan pencegahan terhadap kejadian ISPA saat kabut asap. Himbauan kepada masyarakat agar tidak beraktivitas diluar rumah apabila terjadinya kabut asap dari kebakaran hutan dan lahan di daerah sekitar, menggunakan masker ketika berada di luar rumah, berperan aktif apabila ada penyuluhan yang diberikan petugas kesehatan dalam upaya pencegahan penyakit ISPA, menjaga kebersihan lingkungan didalam atau disekitar rumah dan menjaga kebersihan serta kebersihan udara di sekitar tempat tinggal. Dengan adanya penelitian ini dapat dijadikan acuan perbandingan untuk peneliti selanjutnya sehingga perlu menggunakan indikator yang lebih mendalam mengenai perilaku tindakan pencegahan terhadap kejadian ISPA saat kabut asap dengan desain dan variabel yang berbeda.

\section{DAFTAR PUSTAKA}

1. Suryani, Irma, Edison, \& Julizar, N. (2015). Hubungan Lingkungan Fisik dan Tindakan Penduduk Dengan Kejadian ISPA Pada Balita di Wilayah Kerja Puskesmas Lubuk Buaya. Jurnal Kesehatan Andalas, 4(1), 157167.

2. Mayasari, E. (2015). Analisis Faktor Risiko Kejadian Ispa Ditinjau Dari Status Rumah Di Wilayah Kerja Puskesmas Kota Wilayah Utara Kota Kediri. Jurnal Ikesma, 11, 14-15.

3. Riskesdas. 2018. Badan penelitian dan pengembangan kesehatan kementrian RI tahun 2018. Jakarta : Riskesdas.

4. Dinkes Provinsi Kalimantan Barat. (2018). Profil Keesehatan Kalimantan Barat Tahun 2018: Situasi Derajat Kesehatan 2018. Pontianak: Dinas Kesehatan Provinsi Kalimantan Barat.

5. Dinas Kesehatan Kota Pontianak. (2018). Data Penderita ISPA Di Kota Pontianak. Pontianak, Dinas Kesehatan Kota Pontianak.

6. Ramadhania, Denada. (2016). Hubungan Antara Hotspot dan Kebakaran Terhadap Timbulnya Penyakit Infeksi Saluran Pernapasan Akut (ISPA) Di Kabupaten Kuburaya, Kalimantan Barat. Skripsi. Institut Pertanian Bogor.

7. Lestari, Dwi Mega. (2016). Analisis Spasial Kasus Ispa 
Akibat Kabut Asap Di Wilayah Kerja Uptd Puskesmas Kecamatan Pontianak Utara Tahun 2015. Publikasi Ilmiah, 1-1.

8. Awaluddin. (2016). Keluhan Kesehatan Masyarakat Akibat Kabut Asap Kebakaran Hutan Dan Lahan Di Kota Pekanbaru . Journal Endurance, 1(1), 37-46.

9. Keputusan Menteri Kesehatan RI. (2003). Nomor : 289/Menkes/SK/III/2003. Jakarta: Kementrian Kesehatan Republik Indonesia.

10. Perwitasari, Dian, B. S. (2012). Gambaran Kebakaran Hutan dengan Kejadian Penyakit ISPA dan Pneumonia di Kabupaten Batang Hari, Provinsi Jambi Tahun 2008. Jurnal Ekologi Kesehatan, 11(2), 11.

11. Noor, N.N. (2006). Pengantar Epidemiologi Penyakit Menular. Jakarta: Rineka Cipta.

12. Fithria. (2012). Upaya Keluarga Dalam Pencegahan Penyakit InfeksiSaluran Pernapasan Akut ( ISPA ) pada Balita. Jurnal Ilmu Keperawatan, 1, 27-34.

13. Dharma, Kelana. K. (2015). Metodologi Penelitian Keperawatan. Jakarta: Trans Info Medika

14. Faisal F, Yunus F Dan Harahap F. (2012) Dampak Asap Kebakaran Hutan Pada Pernapasan. Departemen Pulmonologi Dan Ilmu Kedokteran Respirasi, Fakultas Kedokteran Universitas Indonesia - Rs Persahabatan, Jakarta Indonesia. Ckd-189no1. 39 No.1.

15. Fibrila, Firda. (2015). Hubungan Usia Anak, Jenis Kelamin, Dan Beat Badan Lahir Anak Dengan Kejadian ISPA. Jurnal Kesehatan
Metro Sai Wawai, 8(2), 8-13.

16. Novita, N. (2008). Hubungan Antara Hospot (Titik Panas) Dengan Timbulnya Penyakit Infeksi Saluran Pernapasan Akut (Ispa) Akibat Kebakaran Hutan Dan Lahan Di Kabupaten Indragiri Hulu Riau Tahun 2007.

17. Widaningsih. (2018). Metode Edukasi Keesehatan dan Manajemen Investigasi Infeksi Saluran Pernapasan Akut (ISPA). IJONHS, 3(1), 42-46.

18. Lebuan, Anthony Widyanata, Agus Somia. (2017). Faktor Yang Berhubungan Dengan Infeksi Saluran Pernapasan Akut Pada Siswa Taman Kanak-Kanak Di Kelurahan Dangin Pura Kecamatan Denpasar Timur Tahun 2014. E-Jurnal Medika, 6(6), $1-8$.

19. Indarti, Siti, Istikomah. (2019). Hubungan Pencemaran Udara Rumah Tangga Dengan Kejadian Infeksi Salura Pernapasan Akut (ISPA) Pada Balita. Jurnal Ilmiah Kesehatan, 4 (1), 37-42.

20. Putra, Angga Pratama, I Nyoman Widajadnja, M. S. (2017). Hubungan Pengetahuan Ibu Dan Sikap Ibu Tentang Penyakit Infeksi Saluran Pernapasan Akut (Ispa) Dengan Tindakan Pencegahan Penyakit Ispa Pada Balita Di Puskesmas Lindu Kecamatan Lindu Kabupaten Sigi Tahun 2015. Medika Tadulako, Jurnal Ilmiah Kedokteran, 4(1), $1-15$.

21. Milo, Salma, A. Yudi Ismanto, Vandri D. Kallo. (2015). Hubungan Kebiasaan Merokok Di Dalam Rumah Dengan Kejadian Ispa Pada Anak Umur 1-5 Tahun Di Puskesmas Sario Kota 
Manado. Ejournal Keperawatan (E-Kp), 3(2), 1-7.

22. Quasim, Muhammad, Indra Dewi. (2018). Hubungan Pengetahuan Dan Sikap Ibu Dengan Pencegahan Infeksi Saluran Pernapasan Akut (Ispa) Pada Balita Di Wilayah Kerja Puskesmas Antang Makassar. Jurnal Ilmiah Kesehatan Diagnosis, 12(6), 681-685.

23. Marwati, Ni Made, I G.A. Made Aryasih, I Made Bulda Mahayana, Ea Al. (2019). Pendampingan Upaya Pencegahan Terhadap Gangguan Penyakit Infeksi Saluran Pernapasan Akut Di Kecamatan Selemadeg Timur Kabupaten Tabanan. Jurnal Pengabmas Masyarakat Sehat, 1(2), 120-127.

24. Hermawan, Asep, Miko, Hananto., \& Lasut, Doni. (2016). Peningkatan Indeks Standar Pencemaran Udara (ISPU) Dan Kejadian Gangguan Saluran Pernapasan Di Kota Pekanbaru. Jurnal Ekologi Kesehatan, 15, 76-86.

25. Sofia. (2017). Faktor Risiko Lingkungan Dengan Kejadian Ispa Pada Balita Di Wilayah Kerja Puskesmas Ingin Jaya Kabupaten Aceh Besar. Jurnal Action: Aceh Nutrition Journal, 2(1), 43-50.

26. Mayasari, E. (2015). Analisis Faktor Risiko Kejadian Ispa Ditinjau Dari Status Rumah Di Wilayah Kerja Puskesmas Kota Wilayah Utara Kota Kediri. Jurnal Ikesma, 11, 14-15. 